\title{
THE EMPEROR'S FAMILY ON GOINS (THIRD CENTURY): IDEOLOGY OF STABILITY IN TIMES OF UNREST
}

\author{
Marietta Horster*
}

In many of his multifaceted studies Lukas de Blois has discussed different aspects of the conception of third-century emperorship and of the views on virtues and qualities of emperors. ${ }^{1}$ These subjects will continue to be points of debate given the hiatuses and discrepancies in the surviving evidence. The last years of discussion made it obvious that not only careful analysis and the consideration of long-term-developments, but also the acceptance of the imperative to sustain antagonisms in ancient authors and to point out the differences of and in sources - authors, inscriptions, coins, monuments etc. - may as well add insights into the concepts of emperor and emperorship in the third century. This paper aims to add one more facet to the complicated issue of third-century conceptions of power and authority.

\section{To whom it may concern...}

A starting point for the discussion of the dynastic impact of members of the Roman imperial family was made by Hildegard Temporini's dissertation Die Frauen am Hofe Trajans in $1978 .^{2}$ In her investigation of the impact of imperial women on the imagery and propagation of Trajan's rule, she demonstrated that Trajan's Roman coinage had a new focus on family members and was meant to be a demonstration

* This paper presents some results of my research-project "Römische Kaiserinnen: Eine Studie zum gesellschaftlichen Diskurs über weibliche Mitglieder des Kaiserhauses vom 1. - 3. Jh. n. Chr." which is financed by the Gerda-Henkel Stiftung.

${ }^{1}$ L. de Blois, The Policy of the Emperor Gallienus (Leiden 1976), 120-174; Idem, 'Traditional Virtues and New Spiritual Qualities in Third Century Views of Empire, Emperorship and Practical Politics', Mnemosyne 47 (1994), 166-176; Idem, 'Emperor and Empire in the Works of Greek-speaking Authors of the Third Century A.D.', in ANRW 2.34.4, 3391-3443.

${ }^{2}$ H. Temporini, Die Frauen am Hofe Trajans. Ein Beitrag zur Stellung der Augustae im Principat (Berlin and New York 1978). 
of the monarchical character of the regime, a regime and dynasty which was going to last beyond the emperor's death and thus would secure internal peace and external power to the Roman people. But, admittedly, in view of the small scale of such family-members-coinage, less than $2 \%$ of the gold coins and only about $0.2 \%$ of the silver coinage of Trajan's Roman mint, ${ }^{3}$ the question lays at hand if such a small output could have any influence on the image of the dynasty and could fashion opinion at all.

Emperors before Trajan, starting with Claudius and Nero, had made even less use of this kind of propagation of women and children, although Vespasian at least had quite a lot of different types with names and images of his two sons on obverses and reverses. Under Titus and Domitian some coins emphasising Iulia Titi and Domitia Longina were issued, whereas the emperors following Trajan had a slightly growing output of coins with obverses explicitly connected to the dynasty by image and legend; many new types of reverses were added in combination with such 'dynastic' obverses. These reverses are supposed to be a crucial factor for the interpretation of such dynastic-coins and therewith, for the relevance and impact of dynastic issues in a specific reign, and for the insight of an individual's concept of emperorship.

The number of such different reverse legends as CONCORDIA, IVNO or PROVIDENTIA AVG. on coins of empresses and Caesars had peaks: Marcus Aurelius coined 22 different reverse types for his wife Faustina the Younger in fifteen years, and Septimius Severus 25 for Julia Domna and 27 for Geta Caesar during a period of eighteen years, 33 for Cornelia Salonina, wife of Gallienus, in fifteen years of reign, and Tetricius Caesar received 24 reverse legends in about one year - the numbers are based on the respective volumes of the Roman Imperial Coinage $(R I C)$ and British Museum Coins of the Roman Empire $(B M C R E)$ publications not counting all the slight variants of such coin legends and the matching images. ${ }^{4}$ Innovations of legends and images on the one hand and repetitiveness on the other hand are a common

${ }^{3}$ R.P. Duncan-Jones, 'Implications of Roman Coinage: debates and differences', Klio 87 (2005), 459-487, 460 n. 8.

${ }^{4}$ In the footnotes the following abbreviations are used: $R I C=\mathrm{H}$. Mattingly et al., Roman Imperial Coinage (London, 1923-); BMCRE = H. Mattingly et al., Coins of the Roman Empire in the British Museum (London and Oxford, 1966-1976); Cohen = H. Cohen, Description historique des monnaies frappes sous l'empire romain communément appelées médailles impériales, (Paris 1880-1892); Kent/Hirmer = J.P.G. Kent, Roman Coins, (London 1978); obv. $=$ obverse; rev. $=$ reverse. 
feature not only on the small numbers of coins minted in the names of members of the imperial family but also of the emperors' coins. Thus, the emphasis on tradition and the remembrance of traditional values and images as well as the accentuation on the diffusion and dissemination of a new focus on certain values and politics seem to have been an integral part of post-Augustan coinage. However, the answer to the questions if imperial coinage was an "important communication medium"5 expressing the policy of an emperor and influencing public opinion or if these messages were lost on most of the coin users, because messages on coins were highly conventional, is still open to debate. ${ }^{6}$ Even if there were no consistent and standardised ways of using the medium of coinage during imperial times, this does not imply, as Olivier Hekster has pointed out, that individual emperors did not try audience targeting and did not attain to reach such an audience. ${ }^{7}$ Most of our modern criteria and evaluations like "liveliness on coins reflects political instability" (why?) are modern constructs and, moreover, are based on the assumption that we are able to know what and how the ancient viewer, the user of the coins, 'saw' and 'understood'.

My conclusions give credit to different opinions as it will be demonstrated, that although the use of specific images as well as words may have been conventional in the course of the first two centuries, in the late second and in the third century, they were sometimes used in such an unconventional way, that either messages or intentions of the earlier traditions were misunderstood or that an emperor did not always control all his mints in like manner.

However, starting from the beginning of the Principate up to the third century, new images, new legends and new combinations of obverses

${ }^{5}$ Duncan-Jones 2005, op. cit. (n. 3), 459.

${ }^{6}$ For main arguments and an overview of the discussion and its protagonists, see B. Levick, 'Messages on the Roman Coinage: Types and Inscriptions', in G. Paul and M. Ierardi (eds.), Roman Coins and Public Life under the Empire (Ann Arbor 1999), 41-60 and O. Hekster, 'Coins and Messages: Audience Targeting on Coins of Different Denominations', in L. de Blois et al. (eds.), The Representation and Perception of Roman Imperial Power. Impact of Empire 3 (Amsterdam 2003), 20-35.

See Hekster 2003, op. cit. (n. 6), 23-24, for his comments on the analysis of coinage types used to propagate liberalitas, annona or Ceres as specific subjects with relevance for the lower strata of Italian and urban society.

8 A. Wallace-Hadrill, 'Image and Authority in the Coinage of Augustus', fournal of Roman Studies 67 (1986), 66-87, at 70, cited by Hekster 2003, op. cit. (n. 6), 26 with approval for his own position that periods of great turmoil like the Civil War of A.D. 68/69 are a 'test case', because 'messages become more forceful' under such circumstances. 
with reverses as well as of legends and images on coins emerged, which can only be explained by a deliberate and careful choice of the emperor or his entourage (including the responsible mint-masters). Especially the sometimes high level of background interference of coin-iconography as well of coin-legends makes it likely that, even if the first ideas and initiatives were made by the emperor, the specific choices and combinations might often have been made by the mint-masters, the experts. ${ }^{9}$ Such a choice for a new imagery, new legends and combinations was obviously meant to propagate a specific image of a ruler. Even if there should be caution and doubt if and to what extent we are able to detect the (desired or non-intentioned) effects on the audience of these imperial coins, ${ }^{10}$ we are at least able to get an insight into the emperor's or his

${ }^{9}$ With further references to the discussion on responsibilities of choices, see J.F. Drinkwater, The Gallic Empire. Separatism and Continuity in the North-western Provinces of the Roman Empire A.D. 260-274 (Stuttgart 1987), 159-161.

${ }^{10}$ W.E. Metcalf, 'Whose liberalitas? Propaganda and Audience in the Early Roman Empire', Rivista italiana di numismatica 95 (1993), 337-346 and Hekster 2003, op. cit. (n. 6), emphasise that at least in some reigns with few (of a much larger range of) subjects, it seems likely that there was a propaganda-focus on the plebs urbana with the images and legends on aes/bronze issues (congiaria and liberalitates with distribution scenes on sestertii from Nero to Trajan) and a focus on the higher strata of society with silver and gold issues (e.g. the praise of the Praetorians on Claudian coinage, cf. Hekster, 27-28). However, from Hadrian to Trebonius Gallus distribution scenes as well as personifications of liberalitas are to be found on both precious metal and aes coinage. The identification of the targeted audience of the distribution scene coins as the urban plebs based on the assumption by Metcalf, 344 (cf. Hekster, 23 who admits that such boundaries between audiences "must have been somewhat blurred"), that aes coinage had a "primarily Italian and indeed urban circulation" leaves out the western provinces, in which from the second half of the first century to the late second century there were no such active mints like the many early civic mints especially in Spain, the early imperial mints in Lugdunum or Nemausus or the later third-century mints like Sirmium or Cyzicus. Hence, the imperial aes coinage circulated all over the western provinces, as the coin hoards demonstrate as well. Even if one admits that it is likely that a Roman senator or knight and other rich people might more often had denarii and aurei in their hands than aes coins, because they had slaves, freedmen, and freeborn personal who did all the shopping and paid all the small-change-bills, it is still likely that only the very poor would not often come across silver coins and might never see a gold coin during their lifetime. In any case, even if in some cases a targeted audience might be detected, how should we imagine the way of reception of these messages? For a discussion of such methods and for examples of appliance, see J.R. Clarke's stimulating work on the functioning of visual representation within a multilayered system of communication: J.R. Clarke, Art in the Life of Ordinary Romans. Visual Representation and Non-elite Viewers in Italy, 100 B.C.-A.D. 315 (Berkeley, Los Angeles and London 2003), and with a specific focus on coins: P. Lummel, "Zielgruppen" römischer Staatskunst: die Münzen der Kaiser Augustus bis Trajan und die trajanischen Staatsreliefs (München 1991). Lummel, 8, differentiates between the following groups as audience (Zielgruppen) of coin messages: senate, soldiers, plebs urbana, Italians and the provincials. 
entourage's (and mint-masters') preferences and choices in the context of innovations for images and legends on imperial coinage.

The evidence for my subject is the Roman Imperial Coinage, that is to say coins issued by the mints of Rome and of other few western and eastern mints under Roman central authorities, which used Latin legends on obverses and reverses on coins of the Roman denominational system similar to the coins issued by the mint of the City of Rome. ${ }^{11}$

My main arguments are based on the usage of types and legends by different emperors and their mints. This kind of argumentation does not reflect quantity of coins issued and may, therefore, be misleading. ${ }^{12}$ Quantification is necessary if one wants to investigate into the chances that a specific coin might have reached a wider public and thereby might have formed the public image (if possible at all by these forms of communication) of an emperor. In so far, my own investigation might be a kind of methodological fall back without taking into account the quantities of issued coins and without trying systematically to quantify coin circulation, if this is ever possible. But one has to say, there are general problems of quantifications which are not to be overcome with

According to Lummel's quite mechanic and methodologically questionable classification the provincials are addressed e.g. on Trajan's coins with ARABIA and DACIA CAPTA, the soldiers with adlocutio scenes or with FIDES EXERCITVM, the plebs with the $\mathrm{CON}$ (giaria) and circus coins, the senate at the beginning of Trajan's reign with SPQR legends, or with Trajan as togatus etc. (Trajanic coins, ibidem, 79-101). In contrast, R. Wolters, Nummi signati. Untersuchungen zur römischen Münzprägung und Geldwirtschaft (München 1999), 255-339, and others have pointed out that most of the coin-images and coin-legends of the Roman Imperial Coinage were meant to a public in the city of Rome and not to 'the Provincials', the 'Army' et cetera.

11 The different third-century western and eastern imperial mints and their characteristics are discussed in all the introductions to individual reigns in the respective volumes of RIC and BMCRE. For an excellent up-to-date discussion of Aurelianus' ten imperial mints (Antiochia, Cyzicus, Lugdunum, Mediolanum, Rom, Serdica, Siscia, Ticinum, Trier, Tripolis) and the accompanying mint, the so called moneta comitatensis, see R. Göbl, Die Münzprägung des Kaisers Aurelianus, 270/275 (Wien 1993), 31-68. Excluded in this paper are the so-called provincial coinage and the coins of the Greek cities as they both were not under the direct regulation of the Roman central administration and authority, the Greek cities' mints issued other denominations than the Roman imperial ones, and they never used legends (not even in the Greek language) on the reverses the way the Imperial mints did.

${ }^{12}$ For example from the Flavians to the Severans, the AEQUITAS legend dominates all of the virtus coinage by mere quantity of issued coins, aurei, denarii etc., as G.F. Noreña, 'The Communication of the Emperor's Virtues', Fournal of Roman Studies 91 (2001), 146-168, has demonstrated in an examination of 105 hoard finds with the total of nearly 150.000 denarii. If one only relies e.g. on the respective volumes of the $R I C$ the varieties of types would give quite another impression that is a reverse-themesdomination by Victory and only to a lesser extent by different emperor's virtues. 
statistics of hoard finds, as the hoards bear in themselves methodological problems regarding their composition and their dissemination in time and space. ${ }^{13}$

Regional patterns of fineness in silver or gold, in weight and design of coins issued by different imperial mints emerge in the third century when the supply was dispersed to several regional mints in Rome, Italy and some western and eastern provinces. Not only portrait types sometimes varied between different imperial mints but also the reverse legends could differ considerably. However, to my mind, the subject of my paper does allow to rely on the mere evidence of the different types issued, as I am not asking if the general public, the user of the money, the man on the street might have had the chance to receive and look closely at a specific coin, or if everyone understood the specific messages or the symbolic system of coin types of one emperor. Parallel usage of the coins of different emperors, parallel use of coins of one emperor emitted over a long period of time, and the sometimes quite bad state of preservation of coins makes it quite likely that the 'propagation'-effect of single coins or series of coins should not be estimated very high.

\section{The emperors and their family on imperial coins}

The focus of this investigation is on the emperors' and mint-masters' choices of obverse and reverse types concerning the imperial family, the traditions and innovations of such types in the third century from mainly 235 to 284 and the alleged intentions which lay behind such choices as far as they can be conjectured.

${ }^{13}$ On problems of quantifications as such, see C. Howgego, 'The Supply and Use of Money in the Roman World 200 B.C. to A.D. 300', Journal of Roman Studies 82 (1992), 1-31; Idem, 'Coin Circulation and the Integration of the Roman Economy', Fournal of Roman Archaeology 7 (1994), 5-21; T.V. Buttrey, 'Calculating Ancient Coin Production: Facts and Fantasies', Numismatic Chronicle 153 (1993), 338-345; Idem, 'Calculating Ancient Coin Production 2: Why it cannot be done', Numismatic Chronicle 154 (1999), 342-352; Idem, 'The Content and Meaning of Coin Hoards', Fournal of Roman Archaeology 12 (1999), 526-532 (review article). Much more optimistic on the possibilities of quantification (in Leschhorn this case for provincial and civic coinage) than the just mentioned authors is W. Leschhorn, 'Die Kaiserzeitlichen Münzen Kleinasiens: Zu den Möglichkeiten und Schwierigkeiten ihrer statistischen Erfassung', Revue Numismatique 6e ser., 27 (1985), 200-216, but see A. Johnston, 'Greek Imperial Statistics: a Commentary', Revue Numismatique 6e ser., 26 (1984), 240-257. 
It will be demonstrated that by the third century the coins' typology and iconography propagating dynastic themes and arrangements of succession as one means to demonstrate the potential of longevity and security of a reign, has become a kind of standard symbolic visual representation. Even emperors who had no such dynasty, no Caesar or co-Augustus in rule sometimes used dynastic symbols to emphasise their function as guarantors of all civil and military aspects of the Roman Empire, of Roma aeterna. This paper starts with an overview of dynastic themes on imperial coinage and then will give some examples of variations, traditions and innovations of this specific imperial imagery and ideology of the period concerned.

From the late first to the third century dynastic themes have been displayed on coins in two different ways: either with a reference to ancestors in commemorative issues, in the second and third century mainly by consecratio-types, ${ }^{14}$ or with a reference to living family-members. The latter reference to either women of the imperial household or children, especially the Caesars, was made by

- coins of their own, that is, the family member with portrait and name on the obverse, ${ }^{15}$

- coins connecting the family member with the emperor by uniting them either on the obverse of the emperor with both emperor and family member with busts or heads on display on the obverse, ${ }^{16}$

14 Commemorative issues of the second century e.g.: RIC 3, 247 no. 431, denarii, Rome minted by Marcus Aurelius, obv: DIVVS ANTONINVS; rev:: CONSECRATIO with an eagle standing on an altar with garlands; of the third century e.g.: Maximinus Thrax commemorating his wife Paulina RIC 4.2, 153 no. 2, denarius, Rome, obv.: DIVA PAVLINA Paulina bust veiled, rev.: CONSECRATIO Paulina holding sceptre, seated left on a peacock flying to heaven; Decius minted an extensive 'Divi'-series, with types of eleven Divi emperors from Augustus to Alexander Severus, e.g. RIC 4.3, 131 Decius no. 89, antoniniani, Milan; obv. Antoninus Pius radiated DIVO PIO, rev.: eagle CONSECRATIO.

${ }_{15}$ Dynastic themes on the family member's own coins, of the second century e.g.: RIC 2, 388 Hadrian no. 407, denarius, Rome, obv. Sabina's bust SABINA AVGVSTA HADRIANI AVG. P. P., rev. Pudicitia standing left, raises her veil PVDICITIA; of the third century e.g.: RIC 4.2, 13 Macrinus no. 102, Denarius Rome, obv. Diadumenian with bare head M. OPEL. ANT. DIADVMENIAN CAES, rev. Caesar in military dress, holding standard and sceptre, two standards at left side PRING IVVENTVTIS; RIC 4.3, 83 Philip I no. 125c, antoniniani, Rome, obv. M. OTACIL SEVERA AVG, rev. Concordia seated with patera and double cornucopiae CONCORDIA AVGG; RIC 5.2, 163 Carus no. 197, antoniniani, A.D. 282, Siscia, obv. Carinus Caesar with radiated crown M. AVR. CARINVS NOB CAES, rev. Carinus in military dress standing, holding spear and baton PRINCIPI IVVENTVTI (and sign of officina).

${ }_{16}$ Dynastic themes on the obverse in the third century e.g.: Gallienus, gold and silver medaillons, Rome, obv. concordia Augg. and busts of Gallienus and Salonina, RIC 5.1, 
- coins linking one or more family member(s) to the emperor by representing the family member on the reverse of an emperor's coin with him on the obverse. ${ }^{17}$

Apart from the image of a family member and the legend with a name of a family member there are specific visual and verbal codes, indicators, marks as references to the dynastic ideal on coins, which came up and developed during the second century. One such visual code is the combination of someone's image together with the emperor either a coruler Augustus or Caesar or a female member or child of the emperor's family mostly with jugate heads or with capita opposita. The verbal codes are legends like CONCORDIA AVG. or AVGG. with dextrarum iunctio or similar images alluding to the harmony of the couple, the family or the rulers. This concordia legend was one of the first on display of a family-member's own coin and was used on a coin of Iulia, daughter of Titus. ${ }^{18}$ SPES PVBLICA or similar legends refer to the hopeful future of the dynasty, especially to princes; it was introduced by Commodus Caesar under Marcus Aurelius, ${ }^{19}$ whereas LAETITIA PVBLICA was in use since Faustina the younger, ${ }^{20}$ daughter of Antoninus Pius and wife of Marcus Aurelius. The plural of Augustus and it's abbreviation on coins (AVGG. - AVGUSTI/AVGVSTORVM) as qualification and attribute of virtues and victories was a primary code of strength, for two (or even more) men with the highest authority and power protected the Empire and took care of the Roman people.

105 no. 1; 106 no. 1 with rev. Valerian and Gallienus riding, preceded by Victory and accompanied by soldier; RIC 5.2, 152 no. 139 antoniniani, Lyon A.D. 282, obv. jugate busts of Carus radiated and Carinus bare-headed CARVS ET CARINVS AVGG., rev. Pax standing PAX AVG. and officina sign.

${ }^{17}$ Dynastic themes on the reverse of an emperor's coin, of the late second and third century e.g.: RIC 4.1, 115, Septimius Severus no. 181b, Aureus, Rome A.D. 202, obv. Severus' bust SEVERVS PIVS AVG. P. M. TR. P. X, rev. bust of Iulia Domna facing between busts of Caracalla and Geta; $R I C$ 4.3, 73, Philip I no. 43a, Denarius, Rome, obv. Philip's bust IMP M IVL PHILIPPVS AVG., rev. confronted busts of Philip 2 Caesar (bare-headed) and Otacilia PIETAS AVGG.

${ }^{18}$ Iulia Titi and concordia: BMCRE 2, 279 no. 255*; RIC 2, 140 nos. 178-179.

${ }_{19}$ Commodus and spes publica: BMCRE 4, 480 nos. 654-657; 644 nos. 1530-1531; 646 no. 1536; RIC 3, 264 nos. 620-622; 335 nos. 1530-1531; 336 nos. 1543-1545.

${ }^{20}$ Faustina, wife of Marcus, and laetitia publica: BMCRE 4, 159-160 nos. 10461050; 372 nos. 2139-2141; 374-374 nos. 2155-2156; 402 nos. 125-131; 541 nos. 987-988; RIC 3, 94 no. 506; 192 no. 1378; 194 no. 1401; 270 nos. 699-703; 346 nos. $1653-1658$. 
PVDICITIA a reverse legend since Sabina,${ }^{21}$ wife of Hadrian, FEGVNDITAS since Faustina the Younger, ${ }^{22}$ PROPAGO IMPERII since Plautilla, ${ }^{23}$ the different MATER combinations since Faustina the Younger, ${ }^{24}$ the naming of female deities like Venus, Vesta, Ceres, Diana on coins, ${ }^{25}$ - all these coin legend with matching images indicated a woman's sharing in the paragon-character of the imperial household, in the representation of Roman virtues, and were a visible expression of the prospering dynasty. PRINCEPS IVVENTVTIS with the image of a prince was the verbal code of a promising young man, a heir to the thrown, who showed off his military virtues and his leadership skills, being the most noble and the first of all aristocratic adolescents. This coin legend was introduced on a family member's own coin by Domitian Caesar, ${ }^{26}$ whereas the princes of the early Principate, who had taken over the honour, received no official imperial coins of their own. ${ }^{27}$ The first and most eminent feature in the subject of dynastic

${ }^{21}$ Sabina and pudicitia BMCRE 3, 355 nos. 911-913; 537 nos. 1877-1878; RIC 2, 388 nos. 406-407; 389 no. 415; 477 nos. 1032-1033; 478 nos. 1042-1043.

${ }^{22}$ Faustina and fecunditas Augustae BMCRE 4, 398-399 nos. 89-95; 530-531 nos. 902-910; 540 nos. 977-982; RIC 3, 268-269 nos. 675-682; 345 nos. 1634-1641.

23 Plautilla and propago imperï: BMCRE 5, 235-236 nos. 405-410; 322 no. +; RIC 4.1, 269 no. 362; 309 no. 578a; together with Caracalla: RIC 4.1, 222 no. 67.

${ }^{24}$ Faustina, wife of Marcus - matri castrorum, BMCRE 4, 534 nos. 929-931; 542 nos. 989-990; RIC 3, 346 nos. 1659-1664; Crispina, wife of Commodus - matri castrorum BMCRE 4, Commodus, 766 no. 418; Iulia Domna (Severus, Severus and Caracalla; Caracalla alone) - mater deum, matri or mater castrorum, mater Aug(ustorum), mater senatus, mater patr(iae) BMCRE 5.1, 163-64 nos. 47-59; 305 no. 760; 308-309 nos. 771*-774*; 312-13 nos. 788-792*; 432-433 nos. 11-18; 469 nos. 213-214; 472 no. 225; RIC 4.1, 168-69 nos. 562-570; 209 nos. 859-860; 210 nos. 879-884; 273, nos. 380-382a; 310 no. 588; 312 no. 601; Iulia Soaemias, mother of Elagabalus - mater deum, RIC 4.2, Elagabalus, 48-49 nos. 234-248. Cf. Iulia Mamaea - mater castrorum, mater Augusti, but on Severus Alexander's coins, BMCRE 6, 186-187 nos. 729-733 and 736; RIC 4.2, 96 no. $318 *$.

${ }^{25}$ For a general discussion of the verbal or iconographic association of imperial women with goddesses and personifications (not only in imperial coinage), see U. Hahn, Die Frauen des römischen Kaiserhauses und ihre Ehrungen im griechischen Osten anhand epigraphischer und numismatischer Zeugnisse von Livia bis Sabina (Saarbrücken 1994), 322-371; T. Mikocki, Sub specie deae. Les impératrices et princesses romaines assimiliés à des déesse (Rom 1995); A. Alexandridis, Die Frauen des römischen Kaiserhauses. Eine Untersuchung ihrer bildlichen Darstellung von Livia bis Iulia Domna (Mainz 2004), 307-378.

${ }^{26}$ Domitian as princeps iuventutis (under Vespasian) with own coins (aurei, denarii, asses): BMCRE 2, 29 nos. 154-156; 46-47 nos. 260-270; 66 no. 63; 100 no. 481; 171 no. §; 179 no. $747 *$; RIC 2, 41 no. 233; 42 no. 239; 43 nos. 243-46; 60 no. 380; 100 no. 728.

27 Gaius and Lucius Caesares as principes Iuventutis on Augustus' coins in Lugdunum, RIC 12 54 nos. 198-199 (Gaius); 55-56 nos. 205-212 (Gaius and Lucius). For the frequency of Gaius and Lucius and other family-members of the first emperors in civic and provincial coinage, see W. Trillmich, Familienpropaganda der Kaiser Caligula 
aspects on Roman imperial coinage from the first to the third century is continuity: women as well as male members of the emperor's family remained one of the standard themes on coins issued in the imperial mints, however, as in earlier times, they were only a small part of the issued output, even if the number of types concerning the dynastic theme might be quite large. Although there existed this standard set of words and images on coins for the representation of family members from the end of the first to the end of the third century, there were as well constant additions and changes in choices of legends and imagery from the beginning of such representations. Nevertheless, some distinct features in the third century coinage can be noted.

\section{Building a dynasty with gods and deities}

The standard features established in the second century and used throughout the entire third century were the already noted Pudicitia, Fecunditas, Concordia, Venus Genetrix, Iuno Regina and Vesta legends on the reverses of the empresses and the Princeps Iuventutis, Felicitas Publica and/or Spes Publica legends on the reverses of the Caesar's coins.

Changes of the visual codes occurred only late and they are limited to a small period of time. They started in the Gallic empire (A.D. 260-274) and were taken over by Probus in the late 270th. Instead of a second living person associated with a portrait to the emperor, Postumus, Victorinus, and Probus chose obverses only resembling the typical dynastic type with two family members or two co-rulers. ${ }^{28}$ In 263 , Postumus issued gold medaillons, aurei, golden quinarii, silver antoniniani,

und Claudius: Agrippina Maior und Antonia Augusta auf Münzen (Berlin 1978), passim; D. Boschung, Gens Augusta. Untersuchungen zu Aufstellung, Wirkung und Bedeutung der Statuengruppen des julisch-claudischen Kaiserhauses (Mainz 2002), passim; M. Horster, 'Multiple Portraits of Members of Roman Imperial Families in Provincial Coinage', in C. Alfaro, C. Marcos and P. Otero (eds.), Actas del XIII Congreso Internacional de Numismática Madrid 2003 (Madrid), 863-865.

${ }^{28}$ Postumus and Hercules as jugate busts are combined with different reverses: B. Schulte, Die Goldprägung der gallischen Kaiser von Postumus bis Tetricius (Aarau, Frankfurt am Main und Salzburg 1983), 102-119 nos. 108-163, e.g. 119 no. 161, Cologne A.D. 269: obv. POSTVMVS PIVS FELIX AVG jugate busts of Postumus laureate, cuirassed, draped and of Hercules laureate, rev. radiate, draped bust of Sol PACATOR ORBIS, cf. G. Elmer, 'Die Münzprägung der gallischen Kaiser in Köln, Trier und Mailand', Bonner Fahrbücher 146 (1941), 1-106, especially 37-38; in addition, Postumus minted a hole gold series of 'Labours of Heracles' in A.D. 267/268, see Schulte 1983, 106-117 nos. 120-155, cf. Elmer 1941, 37, Drinkwater 1987, op. cit. (n. 9) 162-64, 173-174. 
denarii and quinarii of the mint at Cologne with his head or bust on display jugated with the bust of Hercules. ${ }^{29}$ Similar types were chosen by Victorinus in 269/270 joining his portrait with either Sol or Mars. ${ }^{30}$ Both, Postumus and Victorinus combined these obverses most often with different types of representations of Victoria on the reverses. ${ }^{31}$

This fake-family or fake-co-rulership might be seen as a deliberate choice to emphasise the support and help of their favourite gods, gods being stronger and better co-rulers than a second Augustus or Caesar would be. This kind of imagery did not become wide-spread and was only followed by Probus (A.D. 276-282) with his heavenly co-ruler Sol, the god ensuring the security of the empire as the coin's message notifies. ${ }^{32}$

However, this choice was made due to a lack of alternatives. And at least in the case of the usurpers of the Gallic empire it was meant to demonstrate dynastic strength even without dynasty, a strength equal or superior to the simultaneously reigning emperor Gallienus' who had represented his dynasty on many coin types depicting Salonina and their sons Valerian II and Saloninus. ${ }^{33}$ This imagery of pseudodynastic propaganda is paired by Postumus with coin legends suitable of dynastic propaganda like FELICITAS AVGVSTI, PROVIDENTIA AVG. and SAEGVLI FELICITAS, even though in earlier as in later times such legends were already used not only exclusively in the dynastic contexts. ${ }^{34}$ It seems likely that apart from some very specific and individual coin types the Gallic usurpers were looking at Rome and Roman coinage not only in categories of adequate and accepted

${ }^{29}$ RIC 5.2, 357 no. $254=$ Cohen 44 (gold medaillon); 358-359 nos. 260-264, 267, 271-274 and 283 and further references in note 28 above.

${ }_{30}$ Victorinus: obv. jugate busts of emperor and Sol or Mars on aurei, RIC 5.2, 389 no. 21,25 and 30 , cf. 29.

${ }^{31}$ Postumus and Victoria, e.g. Schulte 1983, op. cit. (n. 28), 102-103 nos. 108-110; Victorinus' propagation of victory (cf. Schulte 130-131 nos. 2-7; 132-133 nos. 10-12; 137 no. 29) may be associated with his victory at Autun, cf. Drinkwater 1987, op. cit. (n. 9), 181-182 with further references and discussion.

32 Probus and Sol: Kent/Hirmer 548, cf. RIC 5.2, 80 no. 596 (with variant), Aureus, Siscia, obv. jugate busts of Probus laureate, cuirassed and of Sol radiate, draped, rev. Securitas seated left on throne, holding sceptre in right hand, resting her left on the top of the head SECVRITAS SAECULI (and SIS officina mark).

${ }^{33}$ For another aspect of this kind of iconographic rivalry on coins of Gallienus and Postumus, see Claire Grandvallet's paper in the present volume.

34 Antoniniani with felicitas, Elmer 1941, op. cit. (no. 28), no. 335, providentia. no. 337 ca. A.D. 263, saeculi felicitas no. 593 in A.D. 268, but see Drinkwater 1987, op. cit. (n. 9), 152-153, for the date of the later coin, which should be attributed to a time earlier in Postumus' reign. 
representations of Victory and Peace on coins but also in the propagation of dynastic stability even in cases when they were not able to present such a dynasty of their own.

Even more widespread than these striking examples of 'misuse' or, better to say, of an 'abstract' use of a concrete concepts - family, dynasty - were changes in the character and meaning of the verbal codes as will be demonstrated by few examples.

\section{Augusti, Augustae, Augustorum}

The plural Augustorum which does not refer to two male Augusti but to one Augustus and his empress, the Augusta, occurred on coins for the first time with Gordian III and his wife Sabinia Tranquillina with Concordia Augg. reverses. ${ }^{35}$ The legend Concordia Augg. reverse legend was also used by Philip I and his wife Otacilia Severa, ${ }^{36}$ Philip Caesar used the same legend and Pietas Augustorum as well, ${ }^{37}$ whereas on Otacilia Severa's coins Pietas Augustae referred to her own pietas and the plural was probably used only later, when Philip II had become Augustus. ${ }^{38}$

Fecunditas was used exclusively for women, but with a Fecunditas Augustorum type of Herennia Etruscilla, ${ }^{39}$ her husband Decius is obviously included in this legend on antoninani and sestertii minted in Rome between

${ }^{35}$ RIC 4.3, 41 nos. 249-250 and 252-253 antoniniani and silver quinarii; 53 nos. 340, 341 a sestertii; no. $341 \mathrm{~b}$ asses; 341c dupondii.

${ }^{36}$ RIC 4.3, 83 no. 125a aurei, Rome, obv. bust of Otacilia M OTACIL SEVERA AVG, rev. Concordia seated holding patera and two cornucopiae CONCORDIA AVGG, cf. $R I C$ 4.3, 83 no. 119 a quinarii; no. $119 \mathrm{~b}$ antoniniani.

${ }_{37}$ RIC 4.3, 85 no. 215 antoniniani, Rome, obv. head of Philip M IVL PHILIPPVS CAES, rev. sprinkler, simpulum, jug, knife, lituus PIETAS AVGVSTORVM.

${ }^{38}$ The gold medaillon has Philip 2 Caesaron the obverse, but the reverse with CONCORDIA AVGVSTORVM refers to the Augusti Philip I and Otacilia RIC 4.3, 97 no. 222; Pietas Augustorum on the reverse: antoniniani, Rome RIC 4.3, 215 with Philip Caesaron the obverse; sestertii and asses RIC 4.3, 95 nos. $212 \mathrm{a}-\mathrm{b}$ for Philip I and the bare-headed Cesar Philip 2. With inclusion of the female Augusta in the Augustorum legend in the Roman mint: pietas Augg. for Otacilia (and Philip I) on sestertii and asses RIC 4.3, 93 no. 198a-b, saeculares Augg. in 248 for Otacilia (and Philip I and their son Philip 2) sestertii, dupondii and asses RIC 4.3, 95, nos $199 \mathrm{a}-\mathrm{c}$ and $202 \mathrm{a}-\mathrm{d}$. In theory the last mentioned saeculares and pietas Augg. legends could also refer to the two male Augusti alone, but this seems rather farfetched as these reverse legends are presented on Otacilia's coins, her bust and legend on the obverse.

${ }^{39}$ RIC 4.3, 127 no. 56, antoniniani, Rome, obv. bust of Herennia HER. ETRVSCILLA AVG., rev. Fecunditas standing with patera and cornucopia, with child at her foot FECVNDITAS AVGG, sestertii and asses, 137 no. 135. 
249 and 251, even in the case that at this time her son Herennius was already co-ruler Augustus for whom the reference to fecunditas would be even more senseless. On coins of Herennius Etruscus, nobilissimus Caesar and princeps iuventutis, some reverses have the plural Augusti/ Augustorum referring either to his parents, Etruscilla and Decius, or to himself and his father. ${ }^{40}$

Pax Augustorum is found on antoniniani and aes coinage of Volusian Caesar and his father Trebonian in 251, his father being sole emperor. ${ }^{41}$ In 253, Aemilian and his wife Cornelia Supera used the Concordia Augustorum legend again. ${ }^{42}$ At that time, the plural for emperor and empress seems to have been established on coins as can be seen e.g. with Aurelian and Severina at the beginning of the 270th. The plural Augustorum was also used sometimes in later reigns not only for Concordia and Pietas but for other virtues of the emperors and the family members as well, thus Pax Augg. and Virtus Augg. legends on asses and quinarii of Carinus Caesar in Rome which must have referred to the excellent virtue of Carus Augustus and Carinus Caesar and the peace the Augustus and his Caesar guaranteed. ${ }^{43}$ In Antioch the Virtus Augustorum was even referring to three 'Augusti' on coins of both Caesars, Numerian and Carinus; it blurred the difference in age, authority and power and melted the Caesars and the Augustus into an imperial triad. ${ }^{44}$ At least in coin legends, the way towards the tetrarchic regime was prepared.

\section{Adult Principes Iuventutis}

A second strong verbal code in the dynastic context is the combination of a Caesar's coin with the princeps iuventutis legend. This legend occurred

${ }^{40}$ RIC 4.3, 138 no. 138 antoniniani, Rome, obv. Q HER ETR MES DECIVS C, rev. two clasped right hands CONCORDIA AVGG; aurei and antoniniani nos. 142-143 with rev. PIETAS AVGG.

${ }^{41}$ RIC 4.3, 174 no. 133 antoniniani; 187 no. 240 dupondii or asses.

${ }^{42}$ RIC 4.3, 197 no. 28; 202 no. 64.

${ }^{43}$ Carinus Caesar: Pietas Augg. RIC 5.2, 157 nos. 155-157 antoniniani; Virtus Augg. 158 no. 164 denarii; 159 no. 171 quinarii; Pax Augustorum 159 no. 173 asses; no. 175 semisses. Cf. similar legends used in the Siscia mint on aurei: Victoria Augg. on reverses of Carinus Caesar's obverses, RIC 5.2, 161-162 nos. 191-193.

${ }^{44}$ Carinus Caesar with VIRTVS AVGG on the reverse RIC 5.3, 164 no. 208 antoniniani, Numerianus Caesar RIC 5.3, 190 no. 375 aurei; 191 nos. 378-379 antoniniani; cf. CONSERVATOR AVGGG. (i.e. Sol protecting the empire) on Numerian Caesar's aurei minted in Antioch, RIC 5.3, 190 no. 373. 
first on the own coins of the imperial family-members in connection with issues of Domitian Caesar; ${ }^{45}$ it was in continued use for nearly all Caesars of the second and third centuries.

When Philip Caesar was about 10 year old, he was given the title of Augustus in A.D. 247 and one of the first issues that recorded his new status seems to be a rare antoninianus ${ }^{46}$ with the same die as an aureus which had been used for him as Caesar in Rome: the new Augustus is still characterised as princeps iuventutis. It is unknown if this is the mint's error, or if Philippus Arabs thought it appropriate for a young boy to be princeps iuventutis even as Augustus. But subsequently, princeps iuventutis was in all probability used for adult Augusti: Trebonian and Volusian used this title as Augusti, although for the sestertii of Trebonian, the Roman mint-masters seem to have used a reverse die of Hostilian Caesar. ${ }^{47}$ It is difficult to decide whether such issues as well as those of for example the vota decennalia for Trebonian and Volusian are hybrids with accidentally mismatched obverses and legends, ${ }^{48}$ or if such coin reverses were deliberate choices, therewith demonstrating the complete ignorance of understanding of the intentions and messages of such legends. In any case, traditions of verbal markers to denote the longevity of a dynasty with references to a young Caesar and princeps iuventutis as potential heir to the thrown are seriously disturbed.

If the Lugdunum mint-masters or the emperors Valerian and/or Gallien made a deliberate choice to connect the emperor with the princeps iuventutis honour for Gallien Augustus at the beginning of his shared reign with his father Valerian, starting in A.D. 253, is also open to question. ${ }^{49}$ These antoniniani of Lugdunum are rare and were probably minted only at the very beginning of the reign. At the latest they were issued before A.D. 256, when Gallien's younger brother Valerian II was made Caesar and princeps iuventutis, both titles displayed on several coin issues of different mints. ${ }^{50}$

${ }^{45}$ Cf. above notes 26 and 27 with references.

${ }^{46}$ Cohen $51=R I C 4.3,96$ no. 218 (with var.).

${ }_{47}$ RIC 4.3, 172 nos. 118 and 119 Trebonian; 179 no. 183 Volusian.

${ }^{48}$ Vota decenalia on coins of short reigns, e.g. Gordian III, RIC 4.3, 17 no. 14, Volusian Caesar's coins issued during the short reign of his father Trebonian, RIC 4.3, 187 no. 243.

${ }^{49}$ RIC 5.1, 70 no. 26.

${ }^{50}$ Valerian Caesar as princeps iuventutis: Lugdunum RIC 5.1, 116 no. 5; Rome 117 no. 11,119 nos. 29-30, 120 no. 34; Antioch 120 nos. 37-40. 
Probably at the beginning of his reign in A.D. 276, Probus Augustus had aurei minted in Cyzicus and antoniniani minted in Ticinum with the princeps iuventutis legend. ${ }^{51}$ The Ticinum mint kept this 'tradition' and issued coins for Carinus Augustus and Numerian Augustus with the princeps iuventutis title respectively, using different reverse dies as those they had used for princeps iuventutis coins earlier in the reign of Carus, when both Carinus and Numerian had still been Caesars. ${ }^{52}$ But this does not mean that the Ticinum mint was extraordinarily careless or ignorant - even in Rome, the emperor Carus was presented on Roman semisses as 'First of the Youth', and Numerian had princeps iuventutis coins as Caesar and as Augustus in Rome as well. ${ }^{53}$ It may be that in the case of the Roman Carus coin, the coin is a hybrid and it was Carinus, his son, who was intended to be meant by this reference; but the combination was of an emperor's bust and name on the obverse with a princeps iuventutis reverse. Actually, Carinus Caesar had his own coins referring rightly to the youth-title, for which coins different dies were used than for his father's coins. ${ }^{54}$ However, at least in the specific case of the Roman Carus coin, it seems quite obvious that the mintmasters had mistakenly used a previously unknown reverse die of one of the Caesars for Carus Augustus' coins as well.

If at least some of these Augustus/princeps iuventutis combinations had been a deliberate choice either by the emperor or by one of the responsible mint-masters, this would indicate that the princeps iuventutis honour and title had become a formula representing a general code for dynasty and security. In case that all these examples of rare coins are hybrids, that is to say, that they have been the result of a inadvertent mix of dies, which had been intended and used for other coins, then

${ }^{51}$ RIC 5.2, 115 no. 892, Aureus, Cyzicus, obv. bust of Probus IMP PROBVS AVG., rev. Emperor standing right, holding spear and globe PRINCIPIS IVVENTVTI (sic); cf. RIC 5.2, 49 no. 318 Ticinum. Probus' mints of Ticinum and Siscia issued large series of antoniniani over a long period of time with the legend concordia militum on the reverse, thus emphasising the concordia between emperor and army. In addition to these series, both mints also issued coins with concordia Augusti - although for Probus, as far as we know, there was no partner for this kind of concordia, harmony, no other Augustus, no female Augusta, no Caesar, RIC 4.3, 51 nos. 323-324 (Ticinum); 88 nos. 658-662 (Siscia).

${ }_{52}$ Carinus Augustus: $R I C$ 5.2, 174 nos. 99-100; Numerian Augustus 199 nos. 444-445.

${ }^{53}$ Carus: RIC 5.2, 142 no. 61; Numerian Aug.: 196 nos. 417-421, antoniniani.

${ }^{54}$ Carinus Caesar with princeps iuventutis legends in Lugdunum, Cyzicus, Ticinum and Siscia and Rome, e.g. RIC 5.2, 156 no. 147 Lugdunum; 158 nos. 158-161 Rome antoniniani, 159 no. 81 asses, 159 no. 176 semisses. 
this would mean that - not only in times of short-term emperors like Trebonian, for whom it seems likely that he was unable to give orders to all mints, but also in more stable and longer reigns - mints were not minting according to the emperor's intentions.

\section{Out of control?}

One of the striking examples of an imperial mint out of the control of any authority understanding the Latin language or at least the intended meaning of coin legends and images is Antioch, which - during a short period of time - obviously had no superior Roman official to lead and control it, or if it had one, he was himself unable to fulfil his task in a sensible and reasonable manner. In the years A.D. 249-251, under Decius, Trebonian and Volusian, on the obverses of the antoniniani issued in the mint of Antioch the legends with the names of Hostilian and Herennius Etruscus were a complete mess and unrecognisable. But even worse appears the matching of Pudicitia (which was not only a typical legend and virtue proper of an empress, but also completely absurd and senseless for a man) with the emperors and princes and instead issued the aequitas reverse of the emperor Decius for Herennia Etruscilla and the two Caesars. ${ }^{55}$

Apart from the FECVNDITAS legend already mentioned for Herennia and Decius in the Roman mint a more striking feature is the reference to female deities, which increased significantly on emperors coins in the third century. The traditional Roman deities Iuno, Minerva, Vesta and Venus had been depicted on emperor's coins before, but rather quite sparingly, whereas female personifications such as Victoria, Fortuna, Pietas, Concordia, or Providentia were always prominent in the emperor's coinage of the second and third centuries. These goddesses had been honoured on coins already in the first two centuries on emperor's coins, but to a much smaller extent. The number of explicit references to female deities Iuno, Minerva and Venus augmented in the third century. ${ }^{56}$

\footnotetext{
${ }^{55}$ Pudicitia and Decius: RIC 4.3, 125 nos. 46a-b; Hostilian 146 no. 196a; Trebonian 168 no. 88; Volusian 185 nos. 232-233. Aequitas and Herennia 128-129 nos. 63-64; Herennius Caesar 140-141 nos. 157a-d; Hostilian 146 nos. 194a-c.

${ }^{56}$ Even Diana Lucifera, the goddess of Aricia, a women' deity and cult, was not left out as the rare aureus of Postumus in Cologne demonstrates, Numismatica Ars Classica
} 
On the other side, Faustina the Younger and Iulia Domna, who both had few somewhat 'masculine' coin-legends, were followed in the mid-third century by Salonina, wife of Gallien. All three empresses used not only the empress-typical coins with Venus or Venus Genetrix, but used for example Venus Victrix on their coins, the very Venus referred to on coins of emperors and the princes: ${ }^{57}$ aequitas and moneta Augusta or Augustorum legends and matching images on empresses' coinreverses started with Iulia Domna and were taken over by Salonina. ${ }^{58}$ And the latter introduced fides militum, reflected by concordia militum in the coinage of Aurelian's wife Severina. ${ }^{59}$ But even empresses, such as Otacilia Severa in the 240th, who, different from Salonina, were more conservative in their coin legends, used legends of their husbands. In the case of Otacilia it was the securitas orbis legend, and there were different variations of coin types referring to Rome's millenium-festival. ${ }^{60}$ However, most coin images and legends of the third century empresses continued the path with quite narrow limits of the female propriety, never using any of the extravagant and masculine variants of a Faustina, Iulia Domna or Salonina.

Auction Fune 25, 2003, no. 559: Aureus, Cologne ca. A.D. 260-269, obv. bust of Postumus, POSTVMVS PIVS AVG., rev. Diana advancing with bow and quiver on shoulder, holding torch with both hands DIANA LVCIFERA. For a discussion of the association of Diana on Gallienus' coins, see De Blois 1976, op. cit. (n. 1), 163-164, even though his sophisticated interpretation of Plotinus' influence visible on such an imagery might be somewhat farfetched, especially because coins in honour of Diana Lucifera were already minted by Gordian III and other emperors, e.g. RIC 4.3, 28 no. 127.

${ }^{57}$ Salonina and Venus Victrix: RIC 5.1, 108 nos. 3 and 8 (Lugdunum); 113 no. 37 (Rome), 115 no. 68 (Asia).

${ }_{58}$ Salonina and aequitas publica: RIC 5.1, 109-10 nos. 16-19, 112 no. 44 (Rome); and moneta Augg: 110 no. 22 (Rome).

${ }_{59}$ Salonina and fides militum: RIC 5.1, 192 no. 7, 195 no. 36 (Rome); Severina and concordia militum: RIC 5.2, 315-318 nos. 1-2, 4, 8, 11, 13, 18 and 20 (Lugdunum, Rome, Ticinum, Siscia, Cyzicus, Antioch). On the interpretation of these concordia militum series in the context of Aurelian's death and a discussion on an alleged 'interregnum' of Severina, see Göbl 1993, op. cit. (n. 11), 29-30, 47-48, 56, 60, 65 and 68.

${ }^{60}$ Securitas on Otacilia's aurei: RIC 4.3, 83 no. 124a; legends saeculares Augg., saeculum novum, miliarium saeculum on aurei, antoniniani, sestertii, asses and dupondii: RIC 4.3, 82 nos. 116a-118; 93 nos. 199a-202d. 


\section{Conclusions}

The shifts of meaning in the case of the Augustorum use demonstrates that in some cases the emperor (and his entourage) intended a change in the use of words to strengthen the dynastic moment by the use of the Augustus-plural until then used exclusively for co-rulers, which were now used for Augustus and Augusta or Augustus and the Caesar. ${ }^{61}$ This does not mean that the position, the potential of influence of an empress or Caesar was strengthened. It seems as if the mere existence of the family, the dynasty was intended to be propagated as a powerful potential in analogy to the existence of a second strong adult man. The choice of double portraits of Postumus, Victorinus and Probus with gods point to the same intention: to propagate a dynastic strength, to refer to two powerful rulers.

However, for modern interpretations of propaganda and policy of coin messages it should be a warning, that as in the pudicitia-Antiochia affair or perhaps also in at least some of the 'Augustus as princeps iuventutis' combinations, the mint-masters and inferior officials appear sometimes to have lost sense of the traditional meaning. Additionally, at the beginning of a reign, emperors were not always in full control of all mints, and might not have seen this as their first duty and primary challenge. But the 'hybrids' (unintentionally or intentionally matched obverses and reverses of different emperors or family members) and many other coins such as the already mentioned vota decennalia ones, were coins used and looked at in the same way as coins where an emperor had made a deliberate choice of new coin images and legends or had decided to refer to traditional coin images, gods, virtues et cetera. Perhaps some members of the higher strata of the populace in the Roman Empire noted slight changes or realised that a coin reverse was a hybrid that mixed up dies, but these phenomena were widespread in the third century and not reduced to the coins referring to the dynastic ideal.

The few selected examples discussed in this paper demonstrate that some codes, visual and verbal, lost their specific meaning in the course of the third century. They continued to be used, but sometimes

${ }^{61}$ A similar shift occurred with the Nobilitas legend, and the nobilissimus Caesar title, which also lost its intended meaning at its starting point with Nobilitas Augg. Commodus compared to its use under Philip, as C. Körner, Philippus Arabs. Ein Soldatenkaiser in der Tradition des antoninisch-severischen Prinzipats (Berlin and New York 2002), 107-108, has pointed out. 
perverted or, at least, without the specific context they were meant to refer to. This was not a linear development and it does not mean that the dynastic ideal was lost or renounced. On the contrary, as far as an emperor had control of his mints, he seems to have used the codes and indicators of reference to dynasty to stress and emphasise the strength and longevity of his reign.

Berlin, November 2006 